\section{Men AND Religion ForWARD MOVEMENT}

Cofounded by Fred Smith and Henry Rood in September 1911 as a nationwide campaign, the Men and Religion Forward Movement (MRFM) emerged out of the cooperation between evangelical churches and religious agencies such as the Federal Council of the Churches of Christ, the Young Men's Christian Association, and the Presbyterian Labor Temple. The movement aimed to draw men to Christ and into church membership, as well as to remasculinize Christianity and evangelical churches and to diminish the role that women were increasingly playing in church affairs.

Although the movement never endorsed any political or civic-reform campaign, it adopted an agenda of issues shared by contemporary Social Gospel advocates and Progressive reformers, including social justice, wholesome recreation, better homes, and the elimination of prostitution and saloons. The MRFM was socially more conservative, however, appropriating these issues to promote its goal of remasculinizing evangelical churches. Furthermore, although the movement received support from such prominent women reformers as the settlement-house worker Jane Addams and the Salvation Army national commander Evangeline Booth, it never endorsed women's rights.

The MRFM resembled the "strenuous life" and "muscular Christianity" movements in that it sought to reinvigorate white, middle-class manhood and overturn nineteenth-century Victorian notions of private and public spheres and the "cult of domesticity." White middle-class men had begun to perceive women's longstanding pre-eminent role in church affairs as a problem in the late nineteenth century, when the transition from entrepreneurial to corporate capitalism, the emergence of a mass consumer society, and an intensifying women's rights movement undermined Victorian gender constructs. The movement's organizers hoped to counteract a perceived feminization of American Protestantism and generate a new gender matrix by remodeling evangelical Christianity and its churches through corporate capitalism's sales and advertising techniques, scientific management methods, consumerist appeal, and masculine patterns of control.

The movement ended in April 1912, having attracted more than one million men to meetings in seventy-six cities and more than one thousand towns. Even though it did not realize its goal of bringing three million men to Christ15,000 fewer men joined a church in 1912 than in 1911-its success in other respects became apparent during the 1920s. In
1923 the Presbyterian Church's all-male general assembly disbanded the women's board. In 1924 the advertising executive Bruce Barton published his bestselling The Man Nobody Knows, which depicted the church as a corporate enterpriseand Christ himself as a corporate executive and a virile man. Furthermore, while 39.3 percent of church membership was male in 1906, it had increased to 41.8 percent by 1926 .

The MRFM failed to achieve some of its goals, but it appears to have served as a catalyst for the early-twentiethcentury shift in the gendered balance of power in U.S. Protestant churches. By attempting to combine masculine and evangelical Christian identities, moreover, it raised issues that remained salient throughout the twentieth century, and it may be considered a forerunner of late-twentieth-century Christian men's movements, such as the Promise Keepers.

\section{BIBLIOGRAPHY}

Bederman, Gail. “'The Women Have Had Charge of the Church Work

Long Enough': The Men and Religion Forward Movement of

1911-1912 and the Masculinization of Middle-Class Protestantism.”

American Quarterly 41 (September 1989): 432-465.

Curtis, Susan. A Consuming Faith: The Social Gospel and Modern

American Culture. Baltimore: Johns Hopkins University Press,

1991.

Hopkins, C. Howard. History of the Y.M.C.A. in North America. New York: Association Press, 1951.

Further ReAding

Allen, L. Dean. Rise Up, O Men of God: The Men and Religion

Forward Movement and the Promise Keepers. Macon, Ga.: Mercer University Press, 2002.

Messages of the Men and Religion Movement. 7 vols. New York: Association Press, 1912.

Smith, Fred B. Men Wanted. New York: Association Press, 1911. . A Man's Religion. New York: Association Press, 1913.

\section{Related Entries}

Cult of Domesticity; Evangelicalism and Revivalism; Middle-Class Manhood; Muscular Christianity; Progressive Era; Religion and Spirituality; Social Gospel; Victorianism; Young Men's Christian Association

-Thomas Winter

\section{Men's Clubs}

Since the early 1700s, American men of different classes, ages, races, and ethnicities have established men's clubs to foster 